\title{
Animal husbandry complexity in the crop-livestock farming systems of the New Reclaimed Lands in Egypt
}

\author{
M. Osman ${ }^{1}$ I. Daoud ${ }^{2}$ S. Melak ${ }^{1}$ E. Salah ${ }^{1}$ Y. Hafez ${ }^{1}$ \\ A. Haggah $^{3}$ A. Aboul Naga ${ }^{1}$ V. Alary ${ }^{4}$ J.F. Tourrand ${ }^{5 *}$
}

\section{Keywords}

Livestock - Multiple use - Cropping system - Delta - Nile River - Egypt.

\begin{abstract}
Summary
In Egypt, the New Reclaimed Lands (NRL) are desert lands that surround the Nile delta, which have been developed for irrigated agriculture during the last half century. They have been settled by migrants from diverse origins, including persons with university degrees and landless peasants from the areas of high demographic concentration of the Nile delta and valley. Only few papers describe the farming systems of these small holders in NRL, especially the animal component, livestock practices, crop-livestock integration, performances and diversity. CLIMED Project aims to produce data on these themes to describe and understand better NRL crop-livestock systems, assess their performances and dynamics in today's Egyptian and Mediterranean context, as well as define priorities in terms of research and development policies. We describe the farming systems based on data collected over a year during monthly monitoring, with a sample of thirteen farms in three zones, selected from a larger survey of 160 farms in four zones. Data show the high complexity of these farming systems for three main reasons: the multifunctionality of animal production, the high dependency of livestock on feeds produced on farm, and social factors such as skills and work management at farm level. Directly linked to this complexity, farm monitoring shows the huge challenge of development services in the face of local market uncertainty, the very limited access to land, future constraints in water management, and the little attractiveness of agriculture to young people.
\end{abstract}

The New Reclaimed Lands (NRL) are desert sandy lands located west and east of the Nile delta (Figure 1). They were progressively managed for irrigated agriculture with Nile River water through a complex network of canals, but also with underground water. NRL has been a very ambitious national policy of the successive

1. APRI/ARC, Dokki, Cairo, Egypt.

2. Matruh Governorate, Matruh, Egypt

3. New Beheira Development Project, New Beheira, Egypt.

4. Cirad, UMR Selmet, Icarda-APRI/ARC, Dokki, Cairo, Egypt.

5. Cirad, UPR Green, avenue Agropolis, 34398 Montpellier Cedex 5, France.

* Corresponding author

Tel: +33 (0)6 $45113099 ;+33(0) 467615779$

E-mail: tourrand@cirad.fr
Egyptian governments $(1,15,20)$ during the last half century, from Nasser Revolution in the 1950s to the beginning of the 21st century. Three main objectives justified this huge investment: give land to urban and rural people from zones with a high population concentration, especially from the Nile delta and valley; increase production to improve national food security, in a context of high demographic growth; and optimize the use of the Nile water available for agriculture and national needs.

NRL settlement depended on the period but two main types of people accessed land: university graduates in order to incite them to invest in agriculture, and beneficiaries (holding no university degree) to help them out of the landless cycle. Each family received a small land plot, usually $2-5$ feddans (0.8-2 ha) depending on the period $(1970 \mathrm{~s}, 80 \mathrm{~s}, 90 \mathrm{~s})$ and its status, with usually a little more for the graduates, as they were considered more efficient by policy makers. The families paid landownership titles to the State in $10-12$ years. As in all agricultural frontiers $(24,25)$, the 
land price increased a lot, especially in the first years, and many changes affected land issues over the years because of three main factors: firstly, the non-adaptation of many families who decided to leave and sell or rent their lands to other families; secondly, the differences in skills, but also chance, between the settlers to increase and manage land, often associated with the importance of family labor, which led to significant differences in livelihoods after a few years; and thirdly, the efficiency of local social networks, which was a risk insurance and usually could reduce the vulnerability of several small holders.

More recently, medium and large-scale agribusinesses have invested in NRL with the objective to meet the increasing demand for food at national and international levels, especially for grain, fruit and vegetables, as well as for animal products (e.g. poultry, dairy products). These private investments have been supported by the State because of the national interest to reduce food imports, especially with regard urban consumption, and to increase exports. Land allocation and access to Nile water for irrigation are two main mechanisms of public supports. The result has been an ongoing expansion of the irrigated land over the desert area surrounding the Nile delta and low valley in the last years.

Moreover, the medium and large-scale agribusinesses are well integrated in specific supply chains and international markets. To fill the gap between national policies and small holders' demands (18), policy makers have been searching adequate ways to integrate better the small farms into the agribusiness supply and market chains. The recommended model, supported by international agencies, is an association or a cooperative of small holders producing specific commodities or foods for one or more agribusinesses in charge of supply and market activities. However, this is a huge challenge because of the questions and doubts of small production on the attractiveness to integrate the agribusiness system and its capacity to do it $(2,18)$.

The farming systems of small holders in NRL are primarily based on irrigated crops and secondarily on livestock activities, similarly to those of the Nile delta and valley (23) and to most of those in the Mediterranean area $(5,21)$. The fields produce a significant part of the food for the family, e.g. wheat, rice, beans, maize, vegetables, fruit, and the feed for the livestock, especially forage, several crop residues and by-products. On the other hand, the herd produces manure used to improve the organic matter and physical structure of the sandy soil. Both crop and livestock components strongly contribute to the family income. The typical family herd has 1-2 dairy Mediterranean buffalos, 2-3 dairy or breeding cows, no more than 5-6 head of sheep and goats, poultry, ducks, and the traditional pigeons. Some small farmers are more specialized in dairy production and own ten, twelve or up to twenty dairy cows, cattle or buffalos, beside their cropping systems.

CLIMED Project is financed by the Mediterranean national funds implemented by ARIMNet European Program. This research project aims to produce data and references on the crop-livestock farming systems of small holders in NRL in order, firstly, to understand better their strategies and constraints, and, secondly, to inform and induce policy making, especially to define adequate policies focused on small production. This paper describes the crop-livestock farming systems including animal husbandry practices, their performances and their complexity as a consequence of the multifunctionality of livestock and the high crop-livestock

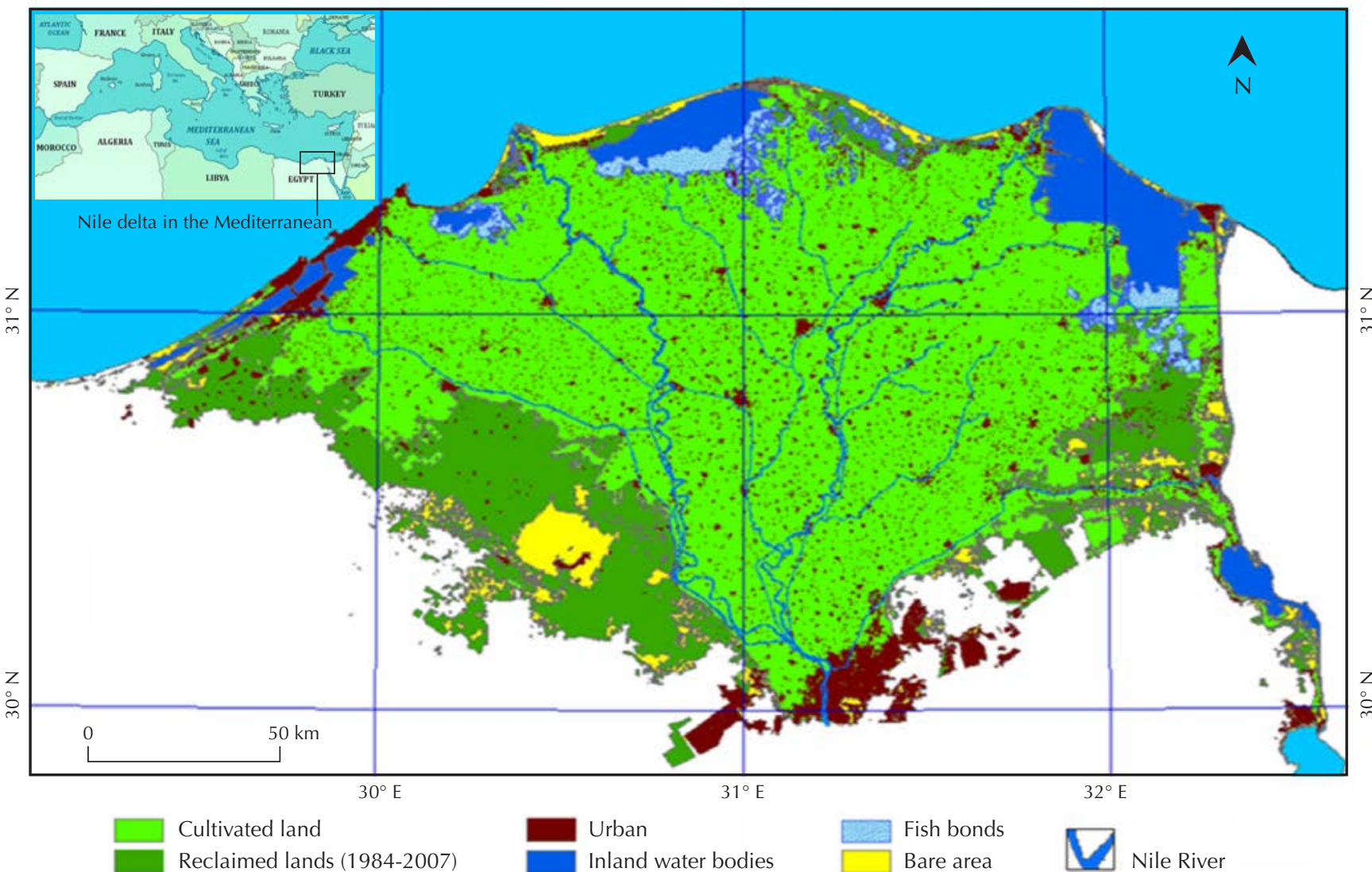

Figure 1: The New Reclaimed Lands (dark green) surrounding the Nile Delta, Egypt, in 2007 (source: CLIMED Project, ARIMNet Program). 
integration. These preliminary results will be first used as a base to build future scenarios at farm and community levels during participative workshops. They will then help draft recommendations for collective actions and policies focused on research, research-development and extension services, especially the implementation of innovative systems and capacity building of farmers and technicians, aiming to bridge the gap between science and society, as recommended in the literature $(13,17,26,27)$.

\section{MATERIALS AND METHODS}

\section{Study area}

In NRL the climate is arid with irregular annual rainfalls, less than $100 \mathrm{~mm}$, except near the coast where they can reach 150 $200 \mathrm{~mm}$. Before NRL, the dry rangeland was grazed by the herds of Bedouin breeders. Today the area consists of a plain with a very low relief, facilitating the building of water infrastructures that are needed for crop irrigation. The settlement is organized in zones where NRL has progressively developed in the last four decades. The oldest NRL are near the traditional delta area and the newest are further away. Each zone has several villages where the farmers and their families live, and they are usually located near their fields. Each village has several hundred to a few thousand families, depending in particular on the size of the land and the history of the zone. In the villages, there are also some shops, trading offices, input providers and basic social services, such as primary and sometimes elementary schools, health centers, mosques, one or a few technicians of extension agencies, depending on the projects implemented in the zone.

Figure 2 shows the Western NRL, selected by CLIMED Project, along the Desert Road between Cairo in the South and Alexandria in the North. Nardha is an old NRL developed in the early 1970s. The other three are more recent, from the end of the 1970s (Tiba) to the end of the 1990s (El Bustan). Agribusinesses have developed substantially during the last fifteen years and are mainly located near the Desert Road. The landscape along the road illustrates well the expansion of agriculture in NRL. In 2005, the Desert Road was only a 2 x 2 lane highway crossing wide desert areas, apart from the presence of a few irrigated farms. Today, it is a large $4 \times 4$ lane highway bordered by two $1 \times 1$ lane roads and secondary roads to access the different towns that emerged progressively.

\section{Sample of thirteen monitored farms}

CLIMED Project firstly developed a large survey, based on questionnaires filled with the data from 160 farms in the four NRL (Figure 2). This survey provided a lot of data on the farming systems, including their structure, management, productions, performances, and human dimension. Secondly, thirteen farms have been selected and monitored monthly during one year to describe their practices and performances in order to define the effects of the

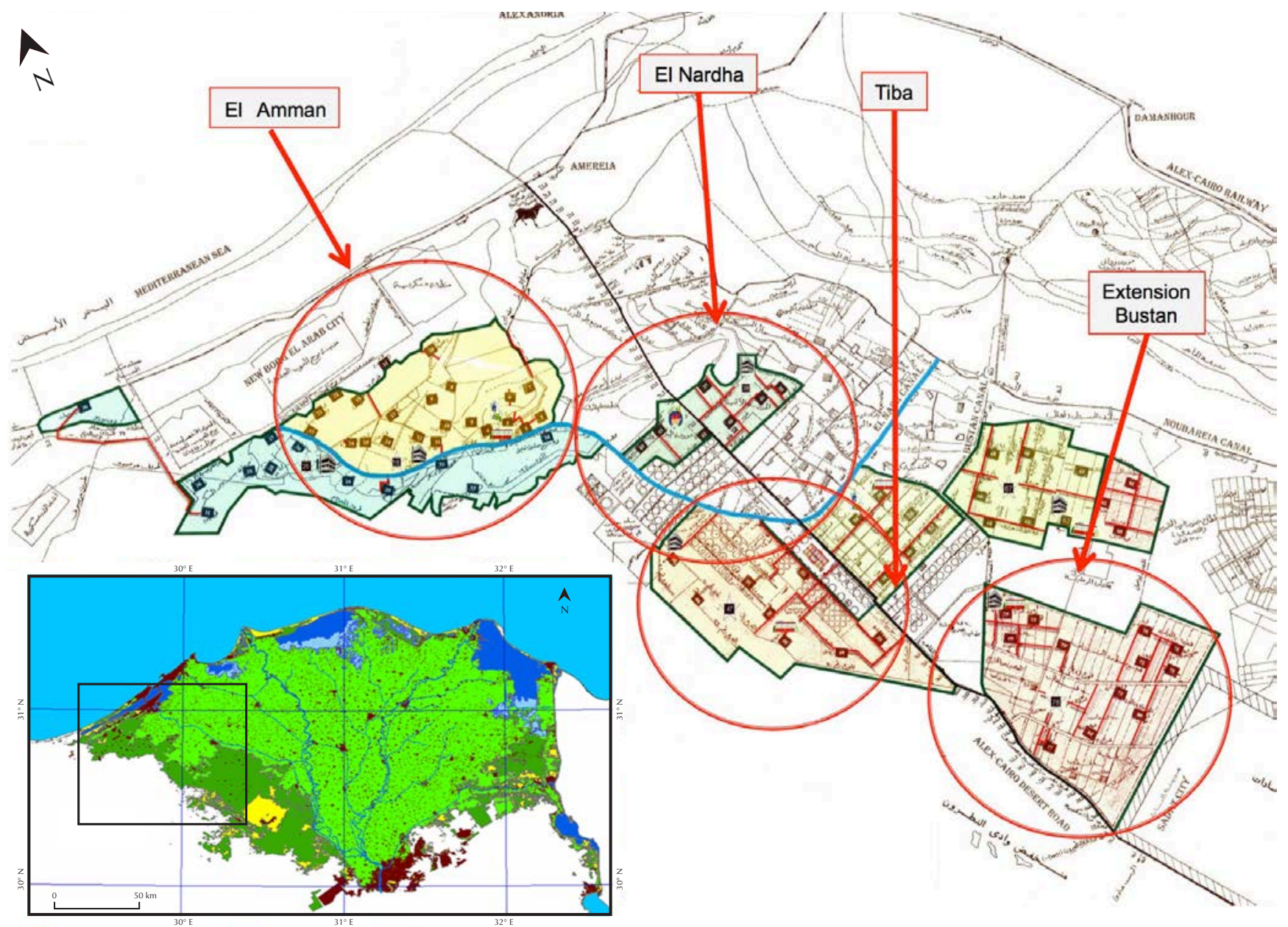

Figure 2: The four research sites in the New Reclaimed Lands along the Desert Road in the Western Nile delta, Egypt (source: CLIMED Project, ARIMNet Program). 
first ones on the second ones, and to help clarify the objectives and strategies of the farmers.

Depending on the local knowledge and the preliminary results of the large survey, the farm diversity might be linked to, at least, the five following structural factors which have been used to select the monitored farms: (i) the settlement period of NRL (1970s, 80s, 90s, 2000s); (ii) the type of farmers (graduates or beneficiaries); (iii) the water origin (from underground water or irrigation canals) and irrigation system (flow and furrow, sprinkler or drip); (iv) the main type of soil (limestone or sand); and (v) the components of the farming system, especially the presence or lack of perennial crops and cash crops, and their interactions with animal husbandry.

The thirteen small farms have been selected for monitoring with the help of the local technicians of extension services according to the criteria previously defined. For logistic reasons, only three NRL were selected: Nardha, Bustan and Tiba. Table I shows the main data for these 13 farms in NRL.

\section{Data collection}

During the monthly visits, data collection focused on the following: - Events and practices in the herd, i.e. calving, lambing and kidding, purchases and sales, death, and information regarding these events, e.g. factors of change, farming decisions;

- Milk production, i.e. the quantity in liters measured by the farmer for each dairy cow, mornings and afternoons, and its uses, e.g. family consumption, cheese processing, sales;

- The feeding system, i.e. the types and quantities of feeds given to the herds, but it was not possible to evaluate the dietary ration for each type of bovine (dairy cow, dry cow, heifer, fattening bull), which was planned for the next phase. Each trimester a detailed feed analysis (net energy and proteins) has been carried out with samples of the different feeds used;

- Various diseases, treatments to the animals and other care.

During the field visits, the data on the cropping systems was also checked for each plot:

- Current land use and forecasts made during the last visit;

- All the events and practices such as new seeding, harvesting and yields, fertilizers and other treatments.

At each visit, we also checked who - between family labor and hired workers - was working, and how many hours a day, with the herd, on the cropping system, and the frequency of irrigation. During the first visit, the history of all the animals and of the land use of each plot were detailed with the farmer and his family. Then, the collected information was directly recorded into the database. A type of farm book gathered an identity card (ID) for each animal and each plot, including a picture (Figure 3). The ID was in English and in Arabic. All the collected data were recorded in the farm book. Information regarding old events and no-recorded events could be integrated in the farm book during the next monthly visit.

A similar procedure was applied to the cropping system. During the monthly visit all the events were detailed with the farmer directly on the plots, then they were recorded in the farm book. The collected data related especially to the land use for each plot, the dates of the various cropping activities (tillage, seeding, treatments, harvesting), the quantity and price of inputs and production, and the labor in hours per day. The farm book included a description of the crop land surveyed during each visit (Figure 4).

Table I

Main data of the 13 monitored farms in Nardha, Bustan and Tiba, in Egypt

\begin{tabular}{|c|c|c|c|c|c|c|c|c|c|c|c|c|c|}
\hline Farm No & 5 & 6 & 7 & 8 & 9 & 10 & 11 & 12 & 13 & 3 & 4 & 1 & 2 \\
\hline Farm code & $\mathrm{ABD}$ & HAM & IZA & KAR & EHA & SAM & SAI & MIS & AFI & ZEE & GAM & MAB & LAT \\
\hline NRL/zone & \multicolumn{5}{|c|}{ El Nardha } & \multicolumn{4}{|c|}{ Tiba } & \multicolumn{4}{|c|}{ El Bustan } \\
\hline Settlement & 78 & 78 & Old & Old & Old & New & New & New & New & 99 & 99 & 97 & 97 \\
\hline Type of farmer & \multicolumn{2}{|c|}{ Beneficiary } & Gra & date & B & G & G & G & G & G & G & B & B \\
\hline Irrigation system & \multicolumn{5}{|c|}{ Flow and furrow } & \multicolumn{6}{|c|}{ Drip and sprinkler } & \multicolumn{2}{|c|}{ Sprinkler } \\
\hline Type of soil & \multicolumn{5}{|c|}{ Limestone } & \multicolumn{8}{|c|}{ Sand } \\
\hline Crop land (feddans) & 9.5 & 7 & 30 & 30 & 8 & 5 & 5 & 5 & 5 & 5 & 5 & 7.5 & 2.5 \\
\hline Perennial crop land (fed.) & 0 & 0 & 0 & 0 & 0 & 2.5 & 2.5 & 5 & 5 & 5 & 5 & 0 & 0 \\
\hline Annual crop land (fed.) & 9.5 & 7 & 30 & 30 & 8 & 2.5 & 2.5 & \multicolumn{4}{|c|}{ Some alley cropping } & 7.5 & 2.5 \\
\hline Bovine & 5 & 18 & 18 & 12 & 10 & 2 & 1 & 3 & 9 & 4 & 10 & 8 & 6 \\
\hline Dairy cow & 2 & 0 & 6 & 6 & 4 & 1 & 1 & 1 & 1 & 2 & 3 & 4 & 2 \\
\hline Dairy buffalo & 2 & 0 & 6 & 6 & 4 & 1 & 1 & 1 & 1 & 2 & 3 & 4 & 2 \\
\hline Heifer & 0 & 0 & 4 & 3 & 2 & 0 & 0 & 0 & 3 & 0 & 0 & 0 & 2 \\
\hline Bull (fattening) & 0 & 0 & 2 & 1 & 2 & 0 & 0 & 0 & 0 & 0 & 2 & 0 & 0 \\
\hline Calf & 2 & 0 & 6 & 2 & 2 & 0 & 0 & 1 & 2 & 1 & 2 & 3 & 1 \\
\hline Sheep and goat & 0 & 6 & 0 & 0 & 0 & 0 & 0 & 0 & 5 & 0 & 0 & 3 & 3 \\
\hline Poultry* & Int & No & No & No & Yes & No & Yes & Yes & Yes & No & Yes & No & No \\
\hline Household & 2 & 2 & 2 & 2 & 1 & 1 & 1 & 1 & 2 & 1 & 1 & 4 & 1 \\
\hline
\end{tabular}

NRL: New Reclaimed Lands in Egypt

* Int: intensive poultry production; Yes/No: significant backyard 


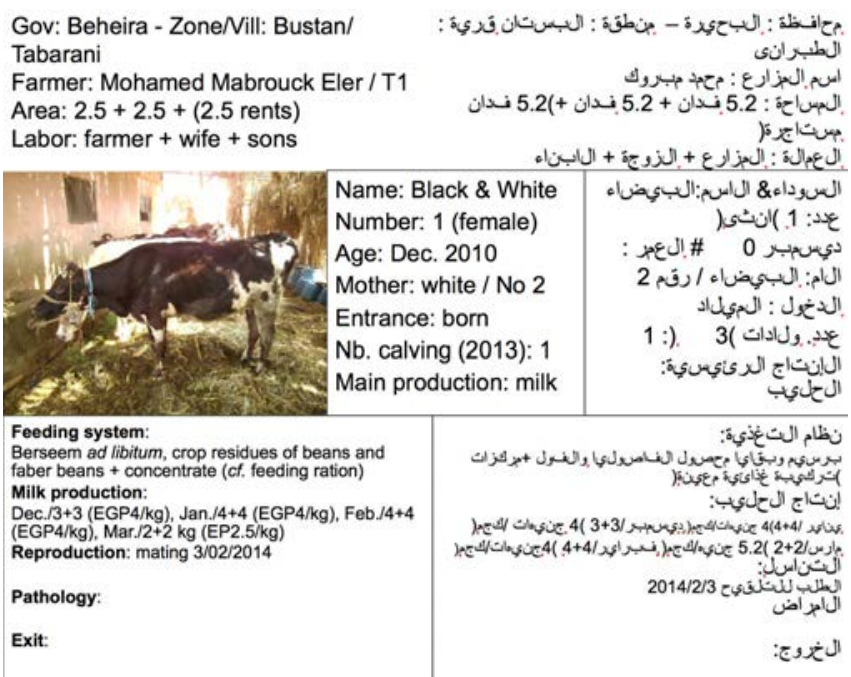

Figure 3: Identity card in English and Arabic of a dairy cow in a monitored farm, in the New Reclaimed Lands of the Nile delta, Egypt.

The objective to record data directly in the farm book during the visit aimed to avoid recording errors and checked the coherence of the data collected during the previous visits. Moreover, after each visit, the team checked again the coherence of the data, focusing on missing or unclear data that were clarified with the farmers during the following visit. This recording system helped prevent many errors because we permanently checked all collected data, including with the farmers, and with the possibility to check furthermore during the next visits, especially in relation with the date of events (calving, entrance and sale), the age of the animals, the number of calvings. In the next phase, a technician and each farmer will put the data directly in a specific farm book on the farm and will transfer them by internet to the database located in the technical assistance office.

Some data were quantitative and related in particular to the structure (e.g. area, number of animals, age at first parturition, inter-parturition time, size of the plots), the animals sold and purchased with prices and dates, the quantity of inputs to feed the herds, various information on the cropping system (yields, dates, prices) and animal production (e.g. calves, lambs, dairy products, manure), including home consumption. Other data were qualitative and concerned in particular the reasons for sales and purchases, changes in feeding and labor, farmers' short, medium and long term strategies for either the cropping or the livestock system. The qualitative data were used to explain the performances and the diversity between the herds, the fields and the farms.

\section{Data analysis}

The successive monthly visits enabled us to carry out on-farm preliminary analyses of the data, and a first assessment of the herd and crop performances directly with the farmer. The most relevant aspects of monitoring lay in the description in detail of the animal husbandry practices, understanding farmers' decision making in relation to management and marketing, checking data and performances, which created an efficient relationship between the research team and the farmers.

Because of the small size of the herds, several parameters were easily evaluated, such as the period between parturitions, milk production (quantity of milk in liters by dairy cow, autoconsumption, processing and sales), changes in the feeding system, costs and revenues, animal diseases, especially mastitis, diarrheas and parasitism,

\begin{tabular}{|c|c|}
\hline $\begin{array}{l}\text { Gov: XXX Zone/village: Bustan/Tabarani } \\
\text { Farmer: Mohamed Abdel Latif / T2 } \\
\text { Area: } 2.5 \mathrm{FD} \\
\text { Labor: Mohamed + workers } \\
\text { Apr14 / Date, quantity, price, market... }\end{array}$ & $\begin{array}{l}\text { In red: data and information } \\
\text { to be checked at the next visit }\end{array}$ \\
\hline \multicolumn{2}{|c|}{$\begin{array}{l}\text { Tillage: + manure } \\
\text { Seeding: Sept. } 13 \\
\text { Fertilizers: nitrates } 50 \mathrm{~kg} / \mathrm{FD} \text { after cut, each } 40 \text { days } \\
\text { Other treatments: } \\
\text { Harvest: } 1 \text { st }=\text { Nov. } 13(50-60 \text { days after seeding) + every } 40 \text { days } \\
1 / 2 \text { Peanuts May-Oct. } 14+1 / 2 \text { dawara (maize forage) and } 5 \text { cuts until Sept. } 1 \text { month } \\
\text { between berseem and dawara }=>\text { just straw and concentrates ( } 5 \mathrm{~kg} \text {, see herd monitoring) }\end{array}$} \\
\hline $\begin{array}{l}\qquad 15 \mathrm{KR}=0.70 \mathrm{FD} / \text { wheat } \\
\text { Tillage: beginning Dec. + manure (?) } \\
\text { Seeding: } 15 / 12 / 13 \\
\text { Fertilizers: (see fertilizers procedure) } \\
\quad \text { urea/nitrates } / \text { sulf, superPl... } \\
\text { Other treatments: urea } 50 \mathrm{~kg}+5 \times 50 \mathrm{~kg} \\
\text { Nitrates (Mar. and Apr.) } \\
\text { Harvest: May, } 3 \text { J } 15 \mathrm{KR}=>12 \text { Ardaps \# } \\
1.8 t=>\text { home consumption + straw } \\
+ \text { beans }\end{array}$ & $\begin{array}{l}\qquad 15 \mathrm{KR}=0.70 \mathrm{FD} / \mathrm{bean} \text { (Fasiola) } \\
\text { Tillage: end of January } \\
\text { Seeding: } 7 / 2 / 14 \\
\text { Fertilizers: manure }(25 / 12 / 13 \text {, see pict.) } \\
\text { Other treatments: urea } 50 \mathrm{~kg}+5 \times 50 \mathrm{~kg} \text { + } \\
\text { nitrates (Mar. and Apr.) + insecticides- } \\
\text { fungicides May, } 20 \\
\text { Harvest: May, } 14,15 \mathrm{KR}=>800 \mathrm{~kg} \\
\text { (EP10/kg).EP16/kg in } 2013 \Rightarrow>\text { Libya } \\
\text { beans }\end{array}$ \\
\hline
\end{tabular}

Figure 4: Example of a record in the farm book of $L A T$, farm in the New Reclaimed Lands of the Nile delta, Egypt, in April 2014. $K R=$ cairot, $14-15$ cairots $=0.70$ feddans

crop deficiencies and parasitism. The functions of the herds were also better defined with concrete examples such as the sale of a dairy cow to finance a brother's marriage of crop inputs, the purchase of a dairy buffalo to produce milk and cheese for the household, or the investment of the income from the crop sale. All data were recorded in the farm books and will be analyzed again in the next phase. The process was the same for the cropping system. During each visit, the research team checked directly with the farmer the different plots, the applied practices, and assessed the development of the crop in relation with the forecasts from the last visits.

The monthly contacts between the farmers and the research team, including the technicians of development agencies who were participating in the farm monitoring, offered several opportunities to exchange about different topics regarding farming systems. Some of them were frequently debated such as the main constraints and ways to prevent them, the impacts of public policies, the technical assistance, the farmers and technicians' demand for training and capacity building, their hopes and fears for the future.

\section{RESULTS}

Two groups of small farms have been identified in the sample (Table I) regarding the role of livestock and herd management. The main group of ten farms (ABD, EHA, SAM, SAI, MIS, AFI, ZEE, GAM, MAB, LAT) focused on family subsistence on small lands of 5-7 feddans (i.e. 2-3 ha), less than 10 feddans (4 ha), small herds, i.e. less than 10 head and less than 5 dairy cows, where cropping was the main activity. The second group of two farms (HAM, KAR) specialized in dairy production with eighteen dairy buffalos for HAM and six dairy cows for KAR, with the medium-term project to reach to 15-20 dairy cows. Cropping was also the main activity. The last farm (IZA) had the characteristics of a small dairy farm but its strategy for livestock was similar to that of the first group. The results presented in this paper mainly concerned the small holders in subsistence situation; the strategies and practices of the other farms were mentioned and detailed when they were different.

Four results are presented in this paper: (i) the multifunctionality of the livestock in the small farms in NRL, (ii) the complex crop-livestock integration, especially the livestock which strongly depended on the feed produced on-farm, (iii) some relevant data 
on the management and performances of these livestock farming systems, and (iv) information regarding the human dimension of these systems.

\section{Multifunctionality of livestock in the small farms in NRL}

Data collection during farm monitoring gave an excellent overview of the multiple functions of the livestock for the small holders in NRL. Seven main roles have been identified, and the first three have been detailed here. In the first role, the livestock produced food for family consumption, including dairy products and meat. In the second and third roles, the herd represented both cash and savings. It financed part of daily expenses, as well as inputs and investments for the cropping system. Thus, the livestock significantly contributed to the livelihood improvement and the vulnerability reduction of the small holders. In the fourth role, livestock was a key factor of crop-livestock integration. The herd produced manure for the cropping system and added value to crop residues, by-products and forages produced by the same cropping system. In the fifth role, family labor made optimum use of animal husbandry. Feeding the animals and caring for them were usually performed by the oldest persons and the teenagers. Milking and cheese making were women's activities. In the sixth role, various activities at local scale depended on animal husbandry, in particular milk and animal traders, veterinarians, inseminators, input providers. The livestock sector was an essential component of the local economy. In the seventh role, animal production strengthened the socio-economic networks by the exchange of experiences, skills, animals, specific tools and innovations at local scale.

\section{Home consumption}

In NRL, part of the dairy production was home consumed, especially buffalo milk and cheese. The remainder was sold or given to neighbors who did not produce (enough) milk. Milk was consumed fresh or as cheese after processing, with some differences between families. The dairy consumption was 1, 2 or 3 liters per household.

Sheep and goats were also consumed by the family, mainly for religious or social events, especially for Aïd El Kebir, the main Muslim celebration, marriages and baptisms. In our sample, farmers declared not being used to selling sheep and goats (Table I). All the production was for home consumption. But, other farmers in NRL villages sold some small ruminants, mainly to their neighbors who needed them for religious and social events. The consumption of buffalo veal was important in Egypt but not in NRL. Similarly, some families used to sacrifice buffalos for Aïd El Kebir, especially young fattened bulls or heifers, and not just sheep and goats.

Poultry was also frequently consumed be the family depending on the uses and demands, especially chickens, ducks, pigeons and eggs. Our sample could be divided into two groups regarding poultry production. One group raised chickens, ducks, pigeons and collected eggs only for home consumption (Table I). The other also produced them to sell them locally or to neighbors or through a trader, depending on the local demand.

The cropping system produced food for family consumption, mainly cereals (wheat, rice and sometimes corn), various beans, vegetables (e.g. cabbage, lettuce, eggplant, onion) and various fruit. Two types of producers have been identified in our sample regarding this system: the farms that specialized in annual crops produced to sell and consumed only a small part of their production; the farms that specialized in perennial crops produced annual crops only for home consumption, especially wheat, some vegetables and fruit.

\section{Sales of livestock products}

The income from the sales of animals, meat and dairy products was another major role of the herd. Regarding milk production, almost all the farmers in NRL sold the milk that was not home consumed, if the price was attractive, when there was an opportunity and enough quantity, even one or two liters per day. The price of buffalo was nearly the same everywhere in NRL, about 5 Egyptian pounds $(\mathrm{EGP})(\approx 0.5 €$, i.e. divided by ten $)$ per liter. The price of cattle milk varied a lot depending on the distance to the market, from EGP 1.5 to 2.5 in NRL, which was about a third to half the price paid to dairy producers located in the suburbs of large cities such as Cairo and Alexandria. There is no milk collection policy in Egypt. Therefore, the local market was weak in NRL, added to the fact that one or two dairy cattle or buffalos were present in almost all the farms. Moreover, each family used to process cheese for home consumption and, eventually, sold a small part directly at the local market or to a trader. In this case, the milk was usually collected directly on the farm by the trader, the milkman, who was also often a dairy producer.

In our sample, six farmers (ABD, SAM, SAI, MIS, ZEE, GAM) declared selling very small quantities of milk, 1-5 liters per day, because their production was very low with only one or two dairy cows. Four small farmers (EHA, AFI, MAB, LAT) declared selling fresh milk every day. The sold quantities depended on the production of their 2-4 dairy cows, i.e. from 2-3 to 15-20 liters per day. These farmers used to sell milk through a milkman who then supplied a milk shop, a milk collection center or a small dairy factory. The last three farmers specialized in milk production; HAM had direct access to the market of Alexandria because he could provide a significant daily quantity of buffalo milk, 150-200 liters. However, he considered stopping the dairy activity and developing fattening production because the labor required for dairy production did not yield enough profit. IZA and KAR sold their milk to the milk collection center located in their villages.

Based on his habits, skills and the need of the family for cash, the farmer would decide to sell small ruminants, calves and lambs after weaning, bulls after fattening, young heifers near first calving, old cows, or dairy cattle or dairy buffalo with suckling calves. Some cases were simple because they only depended on money needs. For example, when families needed EGP 500, EGP 1000 and EGP 1500, in the case of MAB, LAT and AFI, respectively, the farmers decided to sell an old ewe, a young ram, and a ewe with its lamb, respectively. However, the process was very often much more complex and did not only depend on the need for cash. For example, in June 2013, with the money from crop sale, one farmer (LAT) purchased two six-month heifers just after weaning for EGP 8000 for both. He fed them with forages and crop residues produced on farm. He sold them six months later, in February 2014, for EGP 5000 and EGP 6000, respectively. With the money, he purchased a dairy buffalo along with her six-month calf for EGP 11,500, in order to produce buffalo milk for his family, because, two months earlier, in December 2013, he had sold his dairy buffalo and his ten-month female calf to finance his brother's marriage. With the same objective to produce buffalo milk for his family, another farmer (ZEE) sold an old ten-year dairy cow with chronic mastitis with her calf and a fattened eighteen-month bull to purchase a three-year dairy buffalo three months pregnant.

\section{Livestock equals savings}

For all NRL small farmers, using livestock as savings was as important as using it as a provider for home-consumed products and income. LAT previous example showed the complex interconnection between the two functions of livestock, savings and income provider. For the farmers, the three roles were complementary and the 
relative importance of one in relation with the other two depended on the context, i.e. mainly the need for money. ZEE explained that his cattle provided calves which were sold eventually after fattening with by-products and residues of the cropping system. When a cow produced more milk than the calf could ingest, he milked it for home consumption and eventually sold the surplus, even when it consisted of only 2-3 liters. When he needed a lot of money, i.e. more than EGP 2000-3000, he sold one or more animals.

Based on the data collected during farm monitoring, when a farmer needed a few thousand EGP for his family or the cropping system, he sold a young calf (EGP 1500-2000), a heifer (EGP 3000-4000), a cow (EGP 6000-9000) or a buffalo (EGP 8000-10,000), depending on the needs. Conversely, when the farmer received money, for example from the sale of the harvest, he bought some animals and increased his livestock/savings.

Similarly to the trade of milk and dairy products, the animal trade and market chains were complex and varied depending on the villages. Some farmers, such as GAM, used to sell or buy their animals directly at the local market. Others, such as LAT, preferred to go to the markets in their native zones where they had many contacts. These farmers usually had skills in animal trading. Others, less experimented in animal trading, contracted a trader, usually always the same one, who knew the local market, the farm and the farmers' expectations.

\section{Other functions of livestock}

In NRL, the other functions of livestock were less important at farm level, but essential at other levels. Further below, we detailed the relevance of manure in the cropping system, especially for the farms located on sandy soil. MAB considered the production of manure as a major role of his herd. Livestock was also a relevant activity for the oldest and youngest men. For example, in three farms (MAB, AFI, LAT), the grandfathers could no longer work in the fields but they significantly contributed to the farm activity by supervising animal husbandry and caring for the herds all day. They knew all the animals best and were the key informants for data collection of herd monitoring. They were usually helped by the women, especially for milking and to feed poultry, and by the teenagers and young men to feed the herds. On another hand, participating in livestock management was excellent training for the teenagers to become farmers. They were usually responsible for cutting forage in the fields every day, then transporting it near the stables where were kept the ruminants. Moreover, animal husbandry seemed to be an intergenerational activity at family and village levels in NRL, and a key factor to the local society resilience. At local level, livestock interacted with the local economy through the jobs previously mentioned, directly linked to animal husbandry (e.g. trader, veterinarian, inseminator, input and feedstuff provider).

\section{Crop-livestock integration}

The crop-livestock integration is a feature of the agriculture in the Nile delta and valley, as mentioned in the introduction. It relies on two pillars: the manure produced by the herds used as fertilizers, and the animal nutrition based on forage, diverse crop residues and by-products produced by the cropping system. However, beyond the simple equation "Manure - Feed", this integration involves various other factors such as the needs of the crops and the herds depending on the objectives of production, available alternatives for fertilizers and feedstuffs, the work organization on the farm.

\section{Manure as an essential factor of fertility maintenance}

In the farms of the sample, all the manure was used in the cropping system as fertilizers as well as to improve the physical structure of the sandy land, as in the cases of El Bustan and Tiba. In these two villages, the farmers had to put high quantities of manure, $3-5 \mathrm{~m}^{3}$ per feddan ( $0.42 \mathrm{ha}$ ) per year, approximately double that put on clay soils in the Nile delta and valley, and on limestone soils in the old NRL (e.g. El Nardha zone), depending on the local extension services and the farmers themselves.

The production of manure in the farm depended on the feeding system, mainly the quantity of forage and crop residues distributed to the herds. We estimated the production of manure at $2-3 \mathrm{~m}^{3 /}$ year per dairy cattle, and $0.25-0.3 \mathrm{~m}^{3} /$ year per ewe and per goat. In the case of a bovine herd, the stable was usually cleaned every day in the morning. The fresh manure was stored just behind the animal. Some farmers cleaned the stable two or three times a day. The manure of small ruminants and poultry was left on the ground. It was transported in a donkey cart or a horse cart from the stable to the field. It was applied early in the crop cycle, just before tillage or between two tillages. Apparently, there was a great diversity between the farmers regarding manure application in the cropping systems (e.g. type of soil, type of crops, period of application, quantity) but to date we have not collected enough data.

Part of this manure was produced by the farm herd. The remainder originated from the intensive poultry production and was purchased on the market. In order to increase their manure production so as to reduce their need to purchase manure, many farmers tended to give their animals more feeds produced on the farm, especially crop residues which were free, except the cost of transport to the stable. They were given ad libitum because uneaten feeds increased the quantity of manure. Some farmers (e.g. MAB) preferred crops with high residue production to feed their animals in order to increase manure production. However, the farmers' preference for their own production of crop residues, because of their low cost, strongly impacted the feeding system, as detailed further on. Moreover, they needed manure from intensive poultry farms to secure their production.

\section{The feeding system based on forage and crop residues produced on farm}

During the cold season, from mid-autumn (November) to midspring (April-May), the ruminants received clover (Trifolium alexandrinum or berseem) as green forage. Because of the low production of clover in the summer under tropical conditions, the farmers produced maize forage (dawara) for their ruminants, from AprilMay to October-November.

The surface cultivated in green forage depended on the size of the herd, i.e. about one feddan for one or two adult cattle or buffalo. There was no problem to sell the surplus of green forage on the local market because of the high demand. Crop sequences were often clover, maize forage, clover. In March-April, part of the plot was planted with maize forage while the clover was exploited on the other part and progressively substituted with maize forage. Sometimes clover was planted after peanuts, rice, corn for grains, beans or vegetables, and maize forage was planted after wheat, corn for grains, beans or vegetables. Maybe some inadequate sequences led to crop diseases.

In NRL, the green forage was usually cut once or twice a day, mid-morning and in the afternoon, most of the time by teenagers and women, as already mentioned. It was also transported to the farm in a donkey cart. Then it was distributed ad libitum to the ruminants. Some farmers used alfalfa as a perennial forage to feed the ruminants all year round, as in the cases of ZEE and GAM, where alfalfa was planted between the lines of fruit trees (orange and tangerine). 
According to the farmers, the required quantity was $25-30 \mathrm{~kg}$ of green forage for an adult bovine $(250-350 \mathrm{~kg}$ ) and 5-8 $\mathrm{kg}$ for a small ruminant. We estimated that one third to half of the green forage was not eaten by the animals. However, this was not a problem because the uneaten part went to the litter and increased manure production.

A clover plot was cut five or six times from November (approximately two months after seeding) to April, 30-40 days between two cuts, depending on the clover size and feed needs. After each cut, the plot received about $50 \mathrm{~kg}$ of nitrates per feddan $(125 \mathrm{~kg} /$ ha). Clover fixes nitrogen in the nodules of its roots and increases soil fertility for the next crop (wheat, corn for grains, maize forage or vegetables). Also, clover and maize forage planted between two types of vegetables reduce parasitism of crops, especially the number of nematodes.

Because of the difference in feed quality between clover, rich in nitrogen, and maize forage, rich in energy, and consequently the lack of feed produced on the farm in summer, some farmers (e.g. LAT and MIS) sold part of their herds, especially one or two dried cows or buffalos in June-July, and used the money to finance their cropping system. Then they bought dairy cows or buffalos after calving in October-November using the money from the crops.

The herd also received crop residues produced on farm, especially the straw of cereals (rice, wheat, barley and corn), and the stems and leaves of peanuts, various beans and vegetables (e.g. carrots, potatoes, cabbages, eggplants). These crop residues were given during the day and at night, between distributions of green forages. They were distributed the days following harvesting, or they were dried and stored in the field or in the farm, then consumed as hay. Some farmers (e.g. MAB) produced silage from the green straw of cereals. These crop residues were also transported from the field to the farm with a donkey cart or a horse cart.

Daily quantities depended a lot on the farmer's skills, the availability of feed on the farm, green forage and crop residues, and eventually by-products. In several monitored farms (ABD, SAM, SAI, MIS, ZEE, GAM, MAB, LAT), the dietary ration changed every month or every other month in relation to the availability of crop residues and eventually by-products, and was apparently not based on the need of the animals. As already mentioned for LAT and MIS, farmers sold part of their herd, i.e. one or two dairy cows or buffalos or heifers, to avoid buying feeds.

With green forage and crop residues, dairy cows and fattening animals received farm-made concentrates whose composition depended on the farm. Weak and sick animals also received them in order to regain healthy states. Many farmers purchased the products to make the concentrates because they either did not produce them or their production was insufficient. During the milking period, the dairy cattle and buffalos, especially in the dairy farms, usually received concentrates made of bran, crushed corn, peanuts and/or other products and by-products rich in nitrogen or energy, mixed with chopped straw. Cottonseeds and soybeans were also used. The distributed quantity was 2-5 kilograms per day and per dairy cow, depending on milk production. The fattened bulls and lambs received a similar ration with the quantity linked to their needs and the production objectives. According to the farmers, the green forage and crop residues were sufficient for all the other animals. The farm-made concentrates and food residues were at the basis of the poultry ration.

This overview of the feeding systems in the small production in NRL led to three main questions on the dietary ration of the animals and the feeding management by the farmers, except for the two dairy farms where rations were balanced and controlled. The first question concerned the difference between the two green forages: clover which is rich in nitrogen in winter, and maize forage which is rich in energy in summer, and especially the transition from one to the other. The second question concerned the quantity of green forage and crop residues required to meet the needs of the animals. Each farmer had his own practice and criteria to evaluate animal needs. Except for the two dairy farmers, no farmer had received any training or capacity building in animal nutrition. However, a local knowledge was shared by the farmers, mainly through the social-technical network at village scale, and which involved input providers, local specialists (e.g. inseminators, veterinarians), as already mentioned as a main function of livestock. The third question concerned the contribution of the buffalo and the rustic local cattle breed (Baladi) or cross-breed (Baladi x Holstein) to the viability of the system. The buffalo and the Baladi raised by the small farmers in NRL seemed well adapted to these changes in feeding systems.

\section{Livestock management, habitat, composition, structure and performances}

The data collected during the large survey in NRL, which were confirmed by the preliminary results from farm monitoring, showed much variety in livestock management and animal performances. However, it was possible to assess some relevant indices and define the main trends.

\section{Habitat, size and composition of the herds}

The livestock lived in the village, near the family house, in a stable. Cattle and buffalos were usually tied in the stable whereas small ruminants were left free in the corral. The poultry was kept in a specific corral or roamed free in the bovine stable and had a specific place at night.

Table I shows that the typical bovine herd size of small holders was at most 1-2 dairy buffalos and 2-5 dairy cows with their calves, which were kept in the herd or sold after weaning, depending on the needs of the family for cash or investment. Sometimes, one or two young male calves were fattened and sold at 18-20 months to add value to the feed production of the farm. Young heifers were sold because of money needs rather than because of any strategy to renew dairy cows. The farmer usually decided to sell an old cow, and eventually replaced it by a heifer, when he considered that the old cow would not produce any more calves or that its milk production did not outbalance its feed needs. The old cows were usually sold after a small fattening period (two or three months) in order to obtain a better price. A dairy cow was also sold when it was affected by a chronic disease which could impact its future production, calf and milk. However, the strategies for selling and buying animals seemed complex and data on a larger and more representative sample are needed to improve their descriptions. Mainly, we were surprised by the low number of grown heifers in the herds, as if farmers chose to sell their female calves, then purchased heifers near their first calvings.

\section{Breeds and weight performances}

In NRL, the dairy cows were crossbred, Holstein $x$ Baladi, the local breed traditionally used for meat production. This explained the small format of the cattle, i.e. $350-400 \mathrm{~kg}$ for the heaviest cattle. The calf weight was $20-25 \mathrm{~kg}$ for the heaviest, with a daily weight gain of 400-500 g depending on whether the strategy was aimed at the calf or at milk production. These indices were similar to those of the literature (7)

The dairy buffaloes were of the Mediterranean breed. The adult weight was $700-800 \mathrm{~kg}$ and the calf weight $35-40 \mathrm{~kg}$ for the heaviest ones. The daily weight gain of young buffalo was 600-700 g 
per day, i.e. also higher than that of young cattle, and also varied depending on the feeding system and milk production strategy. Milking buffaloes usually started two months after calving because during the first two months all the milk was for the calf.

\section{Animal reproduction}

Regarding reproduction indices, the age at first calving was 3.5 years in cattle and buffaloes, and one year in small ruminants. The interval between calvings depended both on the animals and the feed. It was 17-18 months on average, but this value is not very interesting. Of greater interest is the diversity between the cows, cattle and buffalos. Some had a calf every year and during all their lives, which meant six and up to nine calves. In other cows, the inter-calving period was 12-13 months for the first three or four calvings, but it was longer afterwards, i.e. 18-20 months. Other cows presented an inter-calving period of 16-18 months. Finally, some cows had longer inter-calving periods but the data has not been recorded, and the farmers usually sold them because of this bad parameter. Moreover, the data were not sufficient to find differences between dairy and breeding cattle. In HAM dairy buffalo farm, the calf was immediately sold after calving and the cow was milked during 8-10 months depending on the production, then she was sold to be fattened in specific small feed lots. The ewes and goats usually only had one lambing or kidding per year. However, some had two, which was mainly related to the feeding system and the breed.

Reproduction management was usually carried at village scale. Some farmers and technicians were specialized in animal reproduction, either using males or through artificial insemination. The diversity in the inter-calving period suggested that there were different herd managements and practices regarding reproduction but also animal nutrition.

\section{Dairy production}

The cattle milk production was low with a maximum of four kilograms per milking and two milkings per day, one early in the morning, the other at the end of the afternoon. This quantity did not include the milk for the calf. Total production during a milking period was 800-1200 liters, with about one third for the calf according to the farmer. Considering the small size of the dairy cows (about $350 \mathrm{~kg}$ ), this production was not bad and showed good management of the dairy herd. Moreover, these performances were near those mentioned in the literature (6). The milk production of buffaloes was a little higher, 6-8 kilograms per milking in the more productive dairy buffaloes at the top of the milking period. This result justified the main function of dairy production for the buffaloes whereas cattle were used for double purposes, milk and meat. For both cattle and buffaloes, milk production depended much on the quantity and quality of the concentrates given daily. Dairy production was higher in two dairy farms with 8-10 liters, but some cows produced 12,15 and up to 20 liters at the top of the milking period. However, some dairy cows and buffalos produced 10-12 liters per day, e.g. in the small farms of SAI, AFI and EHA.

The composition and structure of the herds confirmed farmers' word, i.e. one or two dairy buffaloes for home consumption, cattle cows for calves and dairy production in order to provide an income, and the manure for the cropping system. In addition, because the low price of cattle milk in NRL (around or less than $2 \mathrm{EGP} / \mathrm{L}$ ), to produce calves using milk production was also a strategic option. At this price, the potential value of milk production (about 1500 liters) was approximately the same or a little lower than the value of a 6-month-old calf, i.e. EGP 3500-4000 (6).

Concerning the herd size and management of the young males and heifers, the decision about the future of the calves seemed a common dilemma in many farms of NRL. What was best, to sell the calves, males and females, after weaning or to keep the young heifers and/or to fatten the young bulls? When the farmer needed money for his family or his cropping system, he usually sold the calves, taking advantage of the Egyptian market which had a demand for veal. When the farmer did not need money or when he had found an alternative, and if he had sufficient feed, it was a good strategy to keep and raise the heifers and the young bulls. The heifers and the bulls added value every month to his herd. Moreover, the farmer had thus new opportunities in terms of renewal of his old cows and herd reproduction management.

Finally, farm monitoring showed contrasted situations regarding animal diseases. On one hand, the common diseases did not seem to be a major problem in NRL. Many treatments were available in the villages and there were competent technicians. On the other hand, some basic rules in breeding were not applied, e.g. the use of the sun to dry and clean the litter, basic care to the young calves, lambs and kids just after parturition. Moreover, the control of major diseases, such as avian flu or foot-and-mouth disease, was not excellent according to the farmers and technicians.

\section{Human dimension of the farming systems in NRL}

Focused on the description of the crop-livestock farming system, the human dimension had not been included yet in the data collection, except for a few aspects such as those related to multifunctionality. However, farm monitoring identified some constraints in terms of work organization which were analyzed in the next steps; using the monthly calendar of activities during a year provided basic data to model the farming systems (30).

Firstly, according to the farmers (and confirmed during farm monitoring), one NRL irrigated land unit (2.5 feddans or about $1 \mathrm{ha}$ ) required nearly a full-time person for both management and work: 1-2 hours every day to visit and check the crops in the plots; 4-5 hours per day during treatment days and irrigation days, which is equivalent to two or three days per week depending on the season; and a full-time person during harvest and seeding, which was equivalent to 10-15 days two or three times a year. It was not exactly a full time, but it was basically the same because the farmer had to contract workers for a day to be helped with the harvest and later with seeding also for a day. He usually hired 5-6 persons per unit and per day; they were frequently his neighbors. The daily pay for a worker was 50-60 EGP. In return, the farmer helped his neighbors with their harvests and seedings. During this period, when he did not harvest or seed, he spread manure and used the community tractor for tillage. To succeed, the farmer had to integrate rural social networks that gave him access to man power, the tractor and various inputs. He also had to manage all aspects of crop production apart from those on the plots, especially marketing and input purchases. This load explained why a family with just one man usually managed only one irrigated land unit of 2.5 feddans. When there were one or two young men (sons or brothers) also working on the farm, the family could manage two or three units. In the future, we plan to draft calendars of activities for the monitored farms in order to identify better the constraints related to work and work organization.

Secondly, managing cropping systems required confirmed skills. It was not easy to manage four or five crops in two years on the same plot: for example wheat from November to April, peanut from April to September, clover until April, before maize forage, until September-October, or one cereal (corn), or one or two successive vegetables for cash crops from May to August for the first, from September to December for the second.

The young men usually learnt to manage the farming systems with their fathers, brothers or neighbors, starting as family workers 
before having in charge some specific tasks. As previously mentioned, the teenagers' first farm activities were the harvest and transport of clover and maize forage to feed the herds. Then they progressively participated in all the tasks as workers. When the farmers became old and had difficulty going to the fields, their activities focused on livestock, as previously mentioned. According to the young farmers, this charge of livestock manager performed by the older farmers was very important because it impacted herd productivity.

\section{DISCUSSION}

Farm monitoring showed the complexity of crop-livestock farming systems in the small farms of NRL, which resulted from the complexity of each of two components, livestock and cropping system, in addition to their interactions. We analyzed three issues linked to this complexity: firstly, the multifunctionality of livestock, as mentioned by several authors, and the impacts in terms of policy making and extension; secondly, the little interest of young people for rural activities because of the strenuous conditions and low profitability of small-scale farming systems; and thirdly, some priorities in terms of research-development actions adapted to the situation of the small holders in NRL $(17,18)$.

\section{Complexity due to herd multifunctionality and crop-livestock integration}

The livestock farming system in NRL was more than the dual-purpose "milk \& meat" that usually describes small holders $(10,13$, $22,28)$. Our results showed a more complex system with at least five or six other major functions, as mentioned by other authors $(2$, $12,14,18,19,21)$. The livestock farming system produced food for the family (dairy products and meat), an income from the sale of dairy product surplus and animals, as well as manure for the cropping system, and animals for religious events. The livestock also served as savings for the farmer's family. Usually part of the cropping system income and the income from off-farm activities were invested in livestock. In addition, the livestock added value to the cropping system by making optimum use of forages, crop residues and by-products used as feeds. The livestock also developed family labor and rural networks, as previously detailed.

Moreover, these diverse functions were interacting. We showed the synergy between the feed for the herd produced by the cropping system, and the manure produced by the livestock to improve cropping system productivity. Another synergy consisted in the income from the cropping system, eventually from an off-farm activity, being invested in the purchase of animals, which could be sold to finance the cropping system or develop an off-farm activity (e.g. trade, transport). In some other cases, there was competition, for example when milk production was sold and not used for calves, or the straw was burnt after the harvest and not used for feeding. The reasons for burning it included using ashes as fertilizers, the lack of storage space or of labor to transport it to the stable. These interactions determined the indices and the efficiency of the different components of the farming system. According to the literature $(2,9,18,19)$, the interactions between the different roles of animal husbandry can be particularly relevant to explain the farmer's decision process and strategy in terms of productivity and sustainability.

The complexity of crop-livestock farming in NRL seemed particularly high because of the frequent changes in the context, especially the opportunities in crop marketing. This complexity weakened the action of development agencies two ways. Firstly, it invalidated the predesigned packages proposed to farmers and technicians as technological innovations aiming to increase productivity or just one index. For example, the genetic improvement to increase milk production appears unimportant when this production depends on a limited feeding system and when the low price of milk and the last elements of the supply chain do not remunerate the investment. Secondly, the technicians of development agencies do not have the means to face this complexity. Even if they know it well, in totality as in detail, they usually do not have the tools to model it; thus they cannot assess the impacts of their actions, which discourages initiative. Moreover, facing the weak action of the development agencies, the farmers usually adopt short-term secure strategies, which result in a double negative effect: low consideration of medium and long term impacts, and a major constraint for research-development initiatives because of lesser trust between producers and agencies.

\section{Low interest for young people to invest in agriculture, especially in NRL}

Several authors $(6,7,9,16,30)$ mention the high importance of work management on the herd productivity of small farms. The main challenge lies in the need for somebody's presence, every day and many times a day, especially in dairy production. Maybe for that reason, herd management is considered as an old farmer's activity in NRL, as previously mentioned. The presence of a manager is also important in the cropping system, but with less incidence.

Furthermore, because much time is needed to perform the work but profitability is low, many young people planned their future away from the farm, although they usually considered farm life to be rich and pleasant in terms of human relationships within the family as well as in the community. The young men hoped to find a job, very often any kind of job, in the urban area or in the countryside. This mobility of the young men explained the land market. When the young farmer found a job, he usually stopped farming and transferred the land management to his father or brother. Eventually, he rented the land so that he could get it back when the job ended. Moreover, to date, a family with two or three teenagers usually tried to invest by buying or renting plots on the longterm, in order to adapt the cropping area to the family labor and, in the future, transfer the land to the young men. So, farming in NRL was considered as harsh work with low profitability, but also as a secure job. With these mental models, it is complex to imagine innovations to improve the system and increase profitability. Some interesting innovations exist, but they often imply financial or work investment, and the farmers are little able to invest money and work time in their farms.

The little attractiveness of young people to farming, especially livestock farming, is present throughout the world $(11,29)$. It is a big challenge for the future, including in developed and emerging countries. In the case of NRL, and more generally at national scale, agriculture is the last economical sector invested by young students starting at the university. Besides the harsh and low profitability of farming, young people mentioned the bad image of the small farmer because of several factors including environmental impacts and food safety.

\section{What priorities for research and development agencies?}

The farm monitoring information on the structure, functioning and management of the crop-livestock farming systems in NRL helped to identify some of their relevant strengths and weaknesses. 
Moreover, the monthly frequency of the visits enabled us to share and debate these strengths and weaknesses with the local people (e.g. farmers, technicians, traders, input providers). With the tool of participatory research $(4,27)$, farm monitoring led to define better some key issues regarding the sustainable development of these socio-ecosystems, including priorities in terms of research and research-development.

The complexity appeared both as a major strength and constraint. Its major strength lies in the network structure of the farming system. If one segment does not work, one or two others can become active and substitute for it. This is valid for the technical issues as well as for the human ones. For example, if the irrigation system stops during several days or weeks, there is no more green forage. The straw and crop residues of the previous crops can be used to feed the herd. If a farmer cannot work on his farm for health reasons for several days, his social network (family, neighbors and community) take over the most important tasks to prevent major disturbances. The complexity is a constraint because it is very difficult to conceive the many impacts, especially the negative ones, with the integration of any small change or innovation, even with a good knowledge of this complexity. Due to this double feature "strength \& constraint" of the complexity, it is essential to avoid major changes but instead priority should be given to small changes whose impacts will be successively assessed.

Furthermore, there is a deep contrast between the high local knowledge of the farming systems and the non-application of some basic rules in livestock management. For example, all the farmers have access to many drugs and treatments in the village, but they may not take care of the umbilical cords of newborn calves and lambs, or ensure that all the placenta is out after parturition. Or, as previously mentioned, farmers do not use basic practices such as using the sun to dry the litter. Similar examples apply to the cropping systems. The contrast may be linked to the recent settlement of these farmers in NRL, where conditions are different from those in the Nile delta and valley. Nevertheless research-development actions need to understand better the diverse practices in livestock and crop farming systems with a focus on identifying the basic rules that are not applied and develop capacity building and training, both for the farmers and the technicians.

\section{CONCLUSION}

As part of CLIMED Project, monthly farm monitoring collected reliable data on the practices and performances of the crop-livestock farming systems. It also helped clarify further the objectives and strategies of the farmers for their crop-livestock systems in cases where cropping was the main activity. Complexity is one of the major features of these systems in NRL, especially in relation to the animal component because of three main factors: livestock multifunctionality, high dependence on the cropping system for feeding, and human dimension, especially farming labor involving different family members. Because of this complexity, it was not easy to assess satisfactorily the efficiency of these systems in terms of animal nutrition and human resources. However, this efficiency apparently depends on available feed resources during the year, the farmer's skills and his objectives and strategy for his livestock.

Capacity building of local human resources, including farmers and technicians, and specific training on the basic rules of farming systems appear the main priorities in terms of development actions. In a second step, participative workshops and research actions need to focus on understanding better the diversity of these systems so as to propose ways of improving the efficiency of the socio-ecosystem, especially feeding systems and water uses. Finally, similarly to what has been happening in many regions of the world, a major challenge is the low attractiveness of small farming to young people.

\section{Acknowledgments}

This research has been developed within CLIMED Project funded by ARIMNet Program.

\section{REFERENCES}

1. ADRIANSEN H.K., 2009. Land reclamation in Egypt: a study of life in the news lands. Geoforum, 40: 664-674.

2. BALDWIN K.L., DE VEAU V., FOSTER K., MARSHALL M., 2008. Traits affecting household livestock marketing decisions in rural Kenya. In: American Agricultural Economics Association Animal Meeting, Orlando, FL, USA, 27-28 July 2008, $24 \mathrm{p}$

3. BLONDEL M., 2006. The design of Mediterranean landscape: a millennial story of human and ecological systems during the historic period. Hum. Ecol., 34: 713-729.

4. BOUSQUET F., CASTELLA J.C., TREBUIL G., BARNAUD C., BOISSAU S., KAM S.P., 2007. Using multi-agent systems in a companion modeling approach for agroecosystem management in South-east Asia. Outlook Agric., 36: 57-62

5. BROUWER F.M., 2004. Sustainable agriculture and the rural development: Governance, policy and multifunctionality. Chetelham, UK, Edward Elgar Publishing, 384 p. (Coll., Advances in Ecological Economics, Series Eds Jeroen C.J.M, Van Den Bergh)

6. CIRAD, 2007. Les filières laitières dans les pays du Sud. Nouvelles dynamiques et options politiques. Rev. Elev. Méd. Vét. Pays Trop., 60 : 3-223.

7. CIRAD-GRET-MAE, 2009. Mémento de l'agronome. Versailles, France, QUAE, $1700 \mathrm{p}$

8. COURNUT S., MADELRIEUX, S., 2012. Impact sur le travail des transformations des élevages dans des terrains français, marocain, sahélien, brésilien et uruguayen. MOUVE Project/ANR SYSTERA. RMT Travail en élevage. http://idele.fr/recherche/publication/IdeleSolr/ recommends/projet-mouve-ou-lintensification-ecologique-a-lepreuvedes-territoires-volet-travail-premier.html

9. DARNHOFER I., GIBBON D., DEDIEU B., Eds., 2012. Farming systems research into the 21 st century: The new dynamic. Dordrecht, Netherlands, Springer, 490 p.

10. DELGADO C.L., ROSEGRANT M.W., STEINFELD H., EHUI S.K., COURBOIS C., 1999. Livestock to 2020. The next food revolution. International Food Policy Research Institute (IFPRI) (28): 83 p.

11. DONG S., DING L.M., DAOUD I., FASIOLI E., LONG R., ALARY V., CORONATO F., ABDELZAHER, M., ABOUL-NAGA A., SCHWEITZER A., BONAUDO T., TOURRAND J.F., 2013. Adaptation strategies of breeders face global change in harsh conditions. In: 22 nd Int. Grasslands Congress, Revitalising grasslands to sustain our communities, Sydney, Australia, 15-19 Sept. 2013.

12. DUTEURTRE G., FAYE B., 2009. L'élevage, richesse des pauvres : Stratégies d'éleveurs et organisations sociales face aux risques dans les pays du Sud. Versailles, France, Quae, 284 p.

13. FAO, 2013. Global agenda of action for support to sustainable livestock sector development. www.fao.org/ag/againfo/programmes/en/ global_agenda.html

14. GERBER P, MOONEY H.A., DIJKMAN I, TARAWALI S, HANN C., 2010. Livestock in a changing landscape. Experiences and regional perspectives, Vol. 2. Washington DC, USA, Island Press, 210 p. www.fao. org/docrep/013/am075e/am075e00.pdf

15. HANNA F., ABDEL-GHANY O.M., 1995. Agricultural land resources and the future of land reclamation and development in Egypt. In : Abdel Hakim T. Ed., Egyptian agriculture profile. CIHEAM Options Méditerr. Sér. B. Etud. Rech. (9): 15-32.

16. HOSTIOU N., DEDIEU B., BAUMONT B., 2012. Le travail en élevage. Prod. Anim., 25

17. IAASTD, 2008. Agriculture at a crossroads. Synthesis report. Washington DC, USA, Island Press, $106 \mathrm{p}$. 
18. MARTIN F.W., 1988. Beginner's guide to small-scale tropical agriculture. Revised by Yarger L. in 2008. Fort Myers, FL, USA, ECHO, 14 p.

19. MARTIN O., 2012. Why the livestock farming systems are complex objects? Wageningen, Netherlands, EAAP Publication, Wageningen Academic Publ., ISBN 978-8686-761-5.

20. MITCHELL T., 1995. The object of development: America's Egypt. In: Crush J. Ed., Power of development. London, UK / New York, USA, Routledge, p. 129-157.

21. PINTO-CORREIA T., VOS W., 2004. Multifunctionality in the Mediterranean landscapes: past and future. In Jongman R.H.G. Ed., The new dimension of European landscapes. Wageningen, Netherlands, UR Frontis Series, Springer, $257 \mathrm{p}$.

22. ROBINSON T.P., THORNTON P.K., FRANCESCHINI G., KRUSKA R.L., CHIOZZA F., NOTENBAERT A., CECCHII G., HERRERO M., EPPRECHT M., FRITZ S., YOU L., CONCHEDDA G., SEE L., 2011. Global livestock production systems. Rome, Italy FAO, $171 \mathrm{p}$.

23. RUF T., 1988. Histoire contemporaine de I'agriculture égyptienne : essai de synthèse. Paris, France, Orstom, 289 p. ISBN 2-7099-0925-1.

24. SAYAGO D., TOURRAND J.F., BURSZTYN M., DRUMMOND J.A., Eds, 2011. L'Amazonie, un demi-siècle après la colonisation. Versailles, France, QUAE, 271 p.

25. SCHMINK M., WOOD C.H., 1999. Contested frontiers in Amazonia. Gainesville, FL, USA, University of Florida Press, 242 p.

\section{Résumé}

Osman M., Daoud I., Melak S., Salah E., Hafez Y., Haggah A., Aboul Naga A., Alary V., Tourrand J.F. Complexité de l'élevage dans les systèmes d'agriculture-élevage des New Reclaimed Lands (NRL) en Egypte

Les New Reclaimed Lands (NRL, Egypte) sont les terres désertiques entourant le delta du Nil aménagées au cours du dernier demi-siècle pour le développement de l'agriculture irriguée. Elles ont été peuplées par des migrants d'origines diverses, dont d'anciens étudiants et des paysans sans terre en provenance des zones à haute densité démographique du delta et de la vallée du Nil. La littérature aborde peu la production agricole familiale des NRL, en particulier leur composante animale, les pratiques d'élevage, I'intégration agriculture-élevage, leurs performances et leur diversité. Le projet CLIMED vise à produire des données sur ces thèmes pour décrire et mieux comprendre les systèmes agricultureélevage des NRL, évaluer leurs performances et dynamiques dans le contexte égyptien et méditerranéen actuel, ainsi que définir les priorités en termes de recherche et de politique de développement. Les auteurs décrivent les systèmes agricoles à partir des données collectées au cours d'un suivi mensuel d'exploitations sur une année sur un échantillon de treize fermes dans trois zones sélectionnées à partir d'une vaste enquête menée sur 160 exploitations dans quatre zones. Le suivi montre la grande complexité de ces systèmes pour les trois raisons principales suivantes : la multifonctionnalité de l'élevage, la forte dépendance de l'élevage vis-à-vis des aliments produits sur l'exploitation, et les facteurs sociaux en particulier la gestion des compétences et du travail à l'échelle de l'exploitation. Directement lié à cette complexité, le suivi montre l'énorme enjeu des services de développement face aux incertitudes du marché, au faible accès à la terre, aux contraintes futures sur l'eau, de même que la faible attractivité de l'agriculture pour les jeunes.

Mots-clés : Elevage - Objectifs intégrés - Système de culture Delta - Nil - Egypte.
26. STEINFELD H., GERBER P., WASSENAAT T., CASTEL V., ROSALES M., HANN C., 2006. Livestock's long shadow. Environmental issues and options. Rome, Italy, FAO, 380 p. www.fao.org/docrep/010/a0701e/ a0701e00.HTM

27. SUTHERLAND W.J., FLEISHMAN E., MASCIA M.B., PRETTY J., RUDD M.A., 2011. Methods for collaboratively identifying research priorities and emerging issues in science and policies. BES / Methods Ecol. Evol., 2: 238-247.

28. TIESSEN H., BRKLACICH M., BREULMANN G., MENEZES R. Org., 2007. Global change science to society. An assessment and case studies, $68^{\text {th }}$ Edn. Washington DC, USA, Island Press, $280 \mathrm{p}$.

29. TOURRAND J.F., MORALES H., DAOUD I., WAQUIL P., WEDDERBURN L., 2013. Percepções e modelos mentais dos atores locais sobre pecuária. In: 14 Congr. Int. sobre Integração Regional, Fronteiras e Globalização no Continente Americano, UFRGS, Porto Alegre, Brasil, 20-22 Oct. 2013.

30. TURNER M.D., 2009. Capital on the move: the changing relation between livestock and labor in Mali, West Africa. GEOFORUM, 40: 746755 .

Accepted 28 July 2015; Online publication 30 September 2015

\section{Resumen}

Osman M., Daoud I., Melak S., Salah E., Hafez Y., Haggah A., Aboul Naga A., Alary V., Tourrand J.F. Complejidad de la cría animal en los sistemas de fincas agrícolas-ganaderas en las Tierras Recién Reclamadas en Egipto

En Egipto, las Tierras Recién Reclamadas (TRR) son tierras desérticas que rodean el delta del Nilo, desarrolladas durante la último medio siglo para la agricultura con irrigación. Han sido establecidas por migrantes de diversos orígenes, incluyendo personas con diplomas universitarios y jornaleros sin tierra de las áreas de alta concentración demográfica del delta y del valle del Nilo. Pocas publicaciones describen los sistemas agrícolas de estos pequeños propietarios en TRR, especialmente el componente animal, prácticas de cría, integración agricultura-ganadería, rendimientos y diversidades. El proyecto Climed tiene por objetivo producir datos alrededor de estos temas, para describir y entender mejor los sistemas agricultura-ganadería TRR, asesorar sus rendimientos y dinámicas en el contexto mediterráneo y del Egipto de hoy, así como definir prioridades en términos de investigación y desarrollo de políticas. Describimos los sistemas agrícolas basados en datos colectados durante un año de monitoreo mensual, con una muestra de trece fincas en tres zonas, seleccionadas a partir de una encuesta más amplia de 160 fincas en cuatro zonas. Los datos muestran la alta complejidad de estos sistemas agrícolas por tres razones principales: la multifuncionalidad de la producción animal, la alta dependencia del ganado en alimentos producidos en la finca y los factores sociales, tales como manejo del trabajo y la capacidades a nivel de la finca. Directamente ligado a esta complejidad, el seguimiento de las fincas muestra el enorme reto para desarrollar servicios frente a la incertidumbre del mercado local, el acceso muy limitado a la tierra, obstáculos futuros en el manejo del agua y el poco atractivo que representa la agricultura para la gente joven.

Palabras clave: Ganado bovino - Uso multiple - Sistema de culturo - Delta - Río Nilo - Egipto. 